\title{
Identification of Race 1 of Fusarium oxysporum f. sp. lactucae on Lettuce by Inter-Retrotransposon Sequence-Characterized Amplified Region Technique
}

\author{
Matias Pasquali, Flavia Dematheis, Maria Lodovica Gullino, and Angelo Garibaldi
}

Centre of Competence for the Innovation in the Agro-Environmental Sector (AGROINNOVA), Università degli Studi di Torino, via L. da Vinci 44, I-10095 Grugliasco, Torino, Italy.

Accepted for publication 26 February 2007.

\begin{abstract}
Pasquali, M., Dematheis, F., Gullino, M. L., and Garibaldi, A. 2007. Identification of race 1 of Fusarium oxysporum $\mathrm{f}$. sp. lactucae on lettuce by inter-retrotransposon sequence-characterized amplified region technique. Phytopathology 97:987-996.

Fusarium wilt of lettuce, caused worldwide by Fusarium oxysporum $\mathrm{f}$. sp. lactucae, is an emerging seed-transmitted disease on Lactuca sativa. In order to develop a molecular diagnostic tool for identifying race 1 (VCG0300) of the pathogen on vegetable samples, an effective technique

useful for grouping $F$. oxysporum f. sp. lactucae race 1 isolates. Interretrotransposon sequence-characterized amplified regions (IR-SCAR) was used to develop a specific set of PCR primers to be utilized for differentiating $F$. oxysporum f. sp. lactucae isolates from other $F$. oxysporum isolates. The specific primers were able to uniquely amplify fungal genomic DNA from race 1 isolates obtained in Italy, Portugal, the United States, Japan, and Taiwan. The primers also were specific to pathogen DNA obtained from artificially infected lettuce seed and naturally and artificially infected plants.
\end{abstract} is presented. Inter-retrotransposon amplified polymorphism polymerase chain reaction (PCR), a technique based on the amplification of genomic regions between long terminal repeats, was applied. It was shown to be
Additional keywords: diagnostics, IRAP.
Fusarium oxysporum f. sp. lactucae, the causal agent of Fusarium wilt of lettuce (Lactuca sativa L.), is an emerging pathogen causing problems worldwide $(18,20,22,39,70)$ : for example, in Italy, during the last 4 years, it caused up to $70 \%$ of losses in contaminated lettuce fields. The pathogen initially was reported in Japan in 1967, where it was defined as the agent of root rot of lettuce (41). In 1993 and 1998, American and Taiwanese isolates causing wilt on lettuce were determined to be $F$. oxysporum $\mathrm{f}$. sp. lactucum $(30,31)$. Recent studies showed that the two formae speciales are identical in pathogenicity $(21,23)$ and belong to the same group in vegetative compatibility assays (50). Two vegetative compatibility groups (VCGs) have been described as VCG 0300 and VCG 0301 and three races (race 1, 2 and 3) have been identified so far. Race 1 is widespread worldwide and corresponds to VCG 0300, whereas VCG 0301 was found only in Taiwan (50), and its race has not been assigned. Currently, races 2 and 3 have been found only in some regions of Japan $(20,21)$. Despite the use of a different nomenclature for VCG definition, Japanese races 1 and 2 were classified into two different VCGs $(47,71)$.

Molecular techniques utilizing amplified fragment length polymorphism markers or polymorphisms found within the DNA sequence of mitochondrial or nuclear genes have been used to characterize pathogenic groups of $F$. oxysporum (69). These methods have helped define subpopulations and clonal lineages within formae speciales of the $F$. oxysporum species complex $(5,62)$. Alternatively, random amplified polymorphic DNA (RAPD) markers alone have been used to differentiate, for example, f. spp. basilici, (8), phaseoli (2), or chrysanthemi (48).

Corresponding author: M. Pasquali; E-mail address: matias.pasquali@gmail.com

doi:10.1094/PHYTO-97-8-0987

(c) 2007 The American Phytopathological Society
A highly valuable source of specific sequences for developing diagnostic molecular markers is the so-called sequence-characterized amplified region (SCAR) technique $(10,36,54,66)$. This technique commonly uses polymorphisms identified by RAPD markers, followed by sequencing of the DNA for that region for designing primers to be used in polymerase chain reaction (PCR). This approach was used to characterize the three races of $F$. $o x$ ysporum f. sp. lactucae from Japanese origin in pure culture (58).

To characterize diversity among related organisms, the distribution of mobile elements may be used too. Currently, the F. oxysporum genome is largely uncharacterized; however, its genome was estimated to have at least 5\% transposable elements (55). Class II transposons (11-13), that have a cut-and-paste transposition mechanism, have been used as tools for genetic fingerprinting (26). For example Palm (44), an hAT element, encompassed suitable variability for population analysis of $F$. oxysporum f. sp. elaeidis. Transposons such as Fot $1(7,19,49)$ and impala (7) also have been a source of variation for the development of specific PCR markers that allowed the identification of formae speciales and races. Also, class I elements (6) that, in fungi, may represent up to $14 \%$ of the genome (27), have been reported in the $F$. oxysporum genome $(11,28,33)$. One complete retroelement of the copia-like family (Skippy) has been identified, sequenced, and reported to be active $(3,4)$. The use of a class I transposon (transposition via RNA intermediate) for discrimination and characterization of members of the $F$. oxysporum complex has been proposed in the past. For example, Di Pietro and colleagues (16) identified a retrotranscriptase gene related to the Skippy retroelement in different formae speciales and differentiated the $F$. oxysporum groups through restriction fragment length polymorphism analysis using the retroelement as a Southern probe (16). More recently, a SINE element (Foxy) was useful as a tool for characterization of Fusarium spp. and F. oxysporum subgroups (43) and was used for building a mitotic linkage map of $F$. oxysporum 
f. sp. lycopersici (64). A solo long terminal repeat (LTR) sequence (57) named Han was identified during a survey of transposon distribution in the genome (28). LTR insertion sites are conserved in the genome (excluding chromosomic rearrangements and recombination processes). Thus, transposition events don't influence the position of LTR in the genome. The use of LTR for genetic mapping as well as for phylogenetic analysis has been valuable for characterizing primate phylogenies (32), plant diversity (17), and fungal species variability (62). Because LTRs are present in the $F$. oxysporum genome, their use as molecular markers was evaluated here.

A simple method for verifying LTR distribution and mapping variability when LTRs are not more distant than the Taq polymerase extension capacity is the inter-retrotransposon amplified polymorphism (IRAP) technique, first applied to barley by Kalendar et al. (35), but rarely applied to fungi. The IRAP technique is based on the amplification of flanking regions of LTRs. Primers designed for the LTR sequence of the gypsy type element marYl were adopted for differentiating strains of Tricholoma matsutake (45). A modified version of IRAP, based on primers designed on a retrotranscriptase gene, was used for studies of ectomycorrizal basidiomycetes (15).

We describe here the application of the IRAP technique for genetic analysis of $F$. oxysporum, also proposing it as a valuable source for generating SCAR markers that may be applied as interretrotransposon (IR)-SCAR.
The pathogen is spreading, as recently verified in Europe, increasing its specialization (71), and causing important economic losses, especially in the highly profitable sector of preprocessed lettuce; therefore, the use of a fast and efficient method of detection able to identify the most important race of the pathogen on plant samples has become crucial for trying to limit its diffusion (24). The goals of this work were to (i) develop primers for the IRAP technique to be applied to F. oxysporum isolates, in particular for studying the level of variability among $F$. oxysporum from Italian lettuce fields; (ii) evaluate the efficacy of the IRAP technique for discriminating among groups of $F$. oxysporum $\mathrm{f}$. sp. lactucae strains (VCG 0300 to race1); and (iii) develop a molecular tool for pathogen detection on lettuce seed and plants, in order to speed up the procedure that now requires pathogen isolation on a selective medium followed by three possible options: pathogenicity tests, VCG analysis, or the more recently developed diagnostic PCRs (58). In fact, developing an assay for race 1 isolates to be applied on plant material will increase efficiency of seed controls and facilitate analysis of the spread of the disease.

\section{MATERIALS AND METHODS}

Fungal isolates. All isolates used in this study are listed in Table 1. All the Italian isolates were obtained between 2002 to 2004 in the regions of Lumbardy, Piedmont, and Emilia Romagna (northern Italy). These isolates were collected from infected

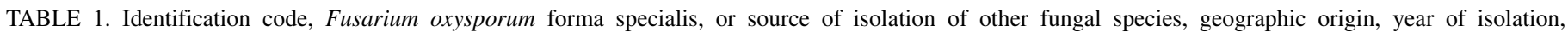
pathogenicity test result, and polymerase chain reaction (PCR) amplification of genomic DNA for each isolate used in this study

\begin{tabular}{|c|c|c|c|c|c|}
\hline Code, isolation source, or genus and species ${ }^{\mathrm{a}}$ & $\begin{array}{l}\text { F. oxysporum f. sp. } \\
\text { or other genus and species }\end{array}$ & $\begin{array}{l}\text { Geographic } \\
\text { origin }\end{array}$ & $\begin{array}{l}\text { Year of } \\
\text { isolation }\end{array}$ & Pathogenicity ${ }^{b}$ & $\mathrm{PCR}^{\mathrm{c}}$ \\
\hline \multicolumn{6}{|l|}{ 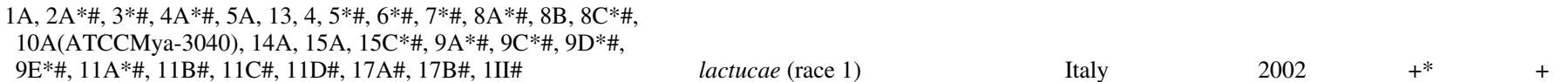 } \\
\hline $1 / 03,9 / 03,12 / 03,13 / 03,14 / 03,20 / 03,26 / 03,28 / 03,29 / 03$, & & & & & \\
\hline 31/03, 7Е\# & lactucae (race 1$)$ & Italy & 2003 & + & + \\
\hline $1 / 04,3 / 04,9 / 04,10 / 04,13 / 04,15 / 04$ & lactucae $($ race 1$)$ & Italy & 2004 & + & + \\
\hline $15 / 06,7 / 06,8 / 06,5 / 06,16 / 06$ & lactucae $($ race 1$)$ & Italy & 2006 & $+^{*}$ & + \\
\hline JCP 0024\# & lactucae $($ race 1$)$ & Arizona & 2002 & $+*$ & + \\
\hline ALFACE & lactucae (race 1$)$ & Portugal & 2005 & + & + \\
\hline ATCC 76616\#, JCP0043\#, JCP0089\#, JCP0163 & lactucae (race 1$)$ & California & 2002 & $+^{*}$ & + \\
\hline AZ-01\#, AZ-02\#, AZ-03\#, AZ-05\# & lactucae $($ race 1$)$ & Arizona & 2002 & $+*$ & + \\
\hline AZ-06\#, AZ-07\#, AZ-08\#, AZ-09\#, AZ-10\# & lactucae (race 1$)$ & Arizona & 2002 & + & + \\
\hline SB1-1\#, SB1-R\# & lactucae $($ race 1$)$ & Japan & Unknown & $+*$ & + \\
\hline 9501\#, 9501R\# & lactucae (race 2) & Japan & Unknown & $+*$ & - \\
\hline MAFF744085, MAFF744086 & lactucae (race 3 ) & Japan & Unknown & NT & - \\
\hline FOL11 (type 2)\#, FOL18 (type 2)\# & lactucae (race 1$)$ & Taiwan & Unknown & $+^{*}$ & + \\
\hline FOL10 (type 1), FOL40 (type 1)\# & lactucum & Taiwan & Unknown & $+^{*}$ & - \\
\hline $1 \mathrm{I}$ \#, 7 I \#, 6 II\# & Unknown (Lactuca sativa) & Italy & 2003 & $-*$ & - \\
\hline 2bis*\# & Unknown (Lactuca sativa) & Italy & 2002 & - & - \\
\hline ATCC 52422\# & chrysanthemi & United States & Unknown & NT & - \\
\hline ATCC16600\# & conglutinans & South Carolina & Unknown & NT & - \\
\hline ATCC16601\# & raphani & United States & Unknown & NT & - \\
\hline ATCC16602 & matthioli & United States & Unknown & NT & - \\
\hline ATCC18141\# & callistephi & California & Unknown & NT & - \\
\hline ATCC52557\# & conglutinans & Wisconsin & Unknown & NT & - \\
\hline ATCC 32724 & tracheiphilum & Nigeria & Unknown & NT & - \\
\hline ATCC58110 & conglutinans & Unknown & Unknown & NT & - \\
\hline АТCC66279 & chrysanthemi & California & Unknown & NT & - \\
\hline ATCC62913 & tracheiphilum & Georgia & Unknown & NT & - \\
\hline ATCC 16608 & tracheiphilum & Unknown & Unknown & NT & - \\
\hline ATCC16609 & tracheiphilum & Unknown & Unknown & NT & - \\
\hline
\end{tabular}

(continued on next page)

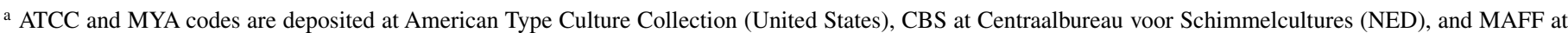
the National Institute of Agrobiological Sciences-NIAS Genebank (Japan). ALFACE was provided by Maria de Lurdes Marques Ramalhete; \# = isolates used in inter-retrotransposon amplified polymorphism PCR; ${ }^{\circ}=$ DNA provided by Liane Gale and Sam Gale, United States Department of Agriculture-Agricultural Research Service.

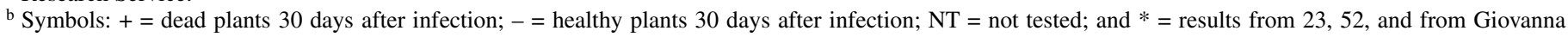
Gilardi (personal communication).

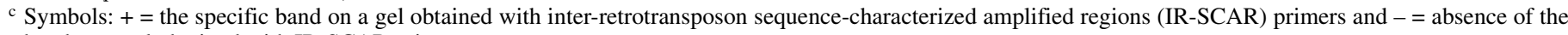
band on a gel obtained with IR-SCAR primers. 
plants through the procedure described previously (22) and are available upon request. Isolates were stored in potato-dextrose agar under mineral oil at $4{ }^{\circ} \mathrm{C}$. Other isolates were kindly provided as acknowledged in previous work (50) by American, Japanese, and Taiwanese colleagues. Only three isolates, belonging to race 2 and 3, could be obtained from Japan. The naturally infected plants that were studied belonged to three different cultivars (Batavia, Multileaf, and Foglia di Quercia) obtained from Az. S. Mauro Pascoli, Emilia Romagna, Italy, in 2006. The 132 isolates used in this study are listed in Table 1.

Pathogenicity and infection assays. Pathogenicity tests were carried out on Italian isolates in 2003 and 2004 and on the Portuguese isolate following the same procedure and conditions as described in (50). Briefly, plants were grown at $25^{\circ} \mathrm{C}$ from commercial seed (cv. Romano Odessa) (Sluis and Groot, Inc., Enkhuizen, The Netherlands) and inoculated after transplantation in plastic pots (one plant per pot, 1-liter capacity, $12 \mathrm{~cm}$ on a side) by adding $5 \mathrm{ml}$ of a conidial suspension $\left(1 \times 10^{6}\right.$ spores $\left./ \mathrm{ml}\right)$ near the crown of plants. Pots were filled with a steam-sterilized mixture containing a 60:20:20 ( $\mathrm{vol} / \mathrm{vol} / \mathrm{vol})$ mixture of peat compost, broadleaf bark, and clay. Pots were watered daily and kept in a controlled-temperature room $\left(25^{\circ} \mathrm{C}\right.$; relative humidity 50 to $90 \%$; daily light conditions, 50 to $60 \mathrm{klx} / \mathrm{m}^{2}, 12 \mathrm{~h} /$ day). Disease progress was measured every 5 days from 30 days after inoculation using a 0 -to- 5 scale, where $0=$ no symptoms; $1=$ slight stunting, no yellowing; 2 = minor wilt and stunting, yellowing (10 to $30 \%$ of leaves); 3 = moderate wilt, stunted, yellowing (30 to $60 \%$ of leaves); 4 = severe wilt, stunted, yellowing (60 to $90 \%$ of leaves); and $5=$ dead (no green leaves). Lettuce plants finally were evaluated; + was assigned when all five plants were completely dead and - when all plants showed no symptoms (Table 1). The test was repeated once. The infection assays on plants and seed, to be used for testing PCR, were performed using isolate 4 (race 1, VCG 0300), isolated in 2002 from a farm in Lumbardy (Italy), and isolate SB1-1, (race 1, VCG0300), obtained from Japan. Artificial infestation of seed and CFU estimation was performed following a similar protocol described for basil seed by Chiocchetti et al. (9). Briefly, 1,000 pathogen-free seed ( $1 \mathrm{~g})$ were shaken at $130 \mathrm{rpm}$ in $4 \mathrm{ml}$ of $4 \times 10^{8}$ conidial suspension. Seed were dried under a sterile air flow for 1 day. One hundred seed were shaken for $5 \mathrm{~min}$ in sterile water. Three separate dilutions of the water used for shaking seed were prepared and $100 \mu$ from each dilution was plated on Komada. CFU was calculated averaging the number of colonies obtained based on three replications. Artificially infested seed was mixed with an increasing percentage of healthy seed. Seed was infested at the following CFU concentrations: 500, 400, 300, 200, 100, 50, and $10 \mathrm{CFU} / 100$ seed. Two separate lots of infested seed were produced for the two isolates and DNA was extracted separately by grinding 100 whole seed, in order to verify possible inhibition of the seed extract in the PCR reaction.

Lettuce plants used for in planta detection were inoculated as described above at $10^{4}$ and $10^{6}$ conidia/ml. Many pieces of surface sterilized roots of each plant, $1 \mathrm{~cm}$ in length, inoculated at

TABLE 1. (continued from preceding page)

\begin{tabular}{|c|c|c|c|c|c|}
\hline Code, isolation source, or genus and species ${ }^{\mathrm{a}}$ & $\begin{array}{l}\text { F. oxysporum f. sp. } \\
\text { or other genus and species }\end{array}$ & $\begin{array}{l}\text { Geographic } \\
\text { origin }\end{array}$ & $\begin{array}{l}\text { Year of } \\
\text { isolation }\end{array}$ & Pathogenicity $^{\mathrm{b}}$ & $\mathrm{PCR}^{\mathrm{c}}$ \\
\hline ATCC16610 & tracheiphilum & Unknown & Unknown & NT & - \\
\hline FOLi & Lilii & Italy & Unknown & NT & - \\
\hline CBS112084\# & chrysanthemi & Italy & Unknown & NT & - \\
\hline FOMK419\# & melonis & Italy & Unknown & NT & - \\
\hline FOG & gladioli & Italy & Unknown & NT & - \\
\hline $251 \mathrm{wt}$ (antagonistic activity) & Unknown (soil) & Italy & Unknown & NT & - \\
\hline $245 w t$ (antagonistic activity) & Unknown (soil) & Italy & Unknown & NT & - \\
\hline FOPR3 & pisi race 3 & Italy & Unknown & NT & - \\
\hline $\mathrm{F} 23^{\circ}$ & pisi race 5 & United States & 1994 & NT & - \\
\hline $\mathrm{F}_{6} 9^{\circ}$ & pisi race 2 & United States & 1994 & NT & - \\
\hline $\mathrm{F} 184^{\circ}$ & pisi race 1 & United States & 1994 & NT & - \\
\hline Fopor & porum & Italy & Unknown & NT & - \\
\hline FoGerbera & chrisanthemi & Italy & 2003 & NT & - \\
\hline FoAnemone & Unknown (Anemone sp.) & Italy & Unknown & NT & - \\
\hline ATCC 204207 & dianthi & Italy & Unknown & NT & - \\
\hline Fuscicl & cyclaminis & Italy & Unknown & NT & - \\
\hline MAFF744004 & cucumerinum & Unknown & Unknown & NT & - \\
\hline MAFF744009 & fragariae & Unknown & Unknown & NT & - \\
\hline MAFF235727 & phaseoli & Unknown & Unknown & NT & - \\
\hline Fusdimorfo & chrysanthemi & Italy & 2004 & NT & - \\
\hline $\mathrm{F} 43 \mathrm{D}^{\circ}$ & Unknown (palm tree) & United States & 2005 & NT & - \\
\hline $\mathrm{F} 119 \mathrm{C}^{\circ}$ & Unknown (palm tree) & United States & 2005 & NT & - \\
\hline Fuspass $^{\circ}$ & passiflorae & United States & 1997 & NT & - \\
\hline $\mathrm{F} 124 \mathrm{C}^{\circ}$ & Unknown (palm tree) & United States & 2005 & NT & - \\
\hline DC $28^{\circ}$ & lycopersici (race 3) & United States & 2000 & NT & - \\
\hline F6123 & linii & United States & 1997 & NT & - \\
\hline Fusela $^{\circ}$ & elaeidinis & Unknown & Unknown & NT & - \\
\hline Fusranunc & Unknown (Ranunculus sp.) & Italy & 2004 & NT & - \\
\hline Fuslisian & Unknown (Eustoma grandiflorum) & Italy & Unknown & NT & - \\
\hline Fuheb $^{\circ}$ & hebae & Unknown & Unknown & NT & - \\
\hline Forl 28\# & radicis lycopersici & Italy & Unknown & NT & - \\
\hline Fol15\# & lycopersici & Italy & Unknown & NT & - \\
\hline MYA-3041 & conglutinans & Italy & 2002 & NT & - \\
\hline MYA-3042 & raphani & Italy & 2002 & NT & - \\
\hline Foltu & tulipae & Italy & Unknown & NT & - \\
\hline Phyt. & Phytophthora sp. & Italy & Unknown & NT & - \\
\hline Fus sol & F. solani & Italy & Unknown & NT & - \\
\hline Fusrose & $F$. roseum & Italy & Unknown & NT & - \\
\hline Fuspro $^{\circ}$ & $F$. proliferatum & United States & 2005 & NT & - \\
\hline Fustab & F. tabacinum & Italy & Unknown & NT & - \\
\hline Rizo & Rhizoctonia solani & Italy & Unknown & NT & - \\
\hline
\end{tabular}


two conidia concentrations were collected at 25 and 14 days postinfection. A water-inoculated plant was included in the infection test as a negative control. Two trials were conducted.

DNA extraction. Genomic DNA was extracted by using a phenol chloroform procedure as described previously $(7,48)$. DNA from seed and artificially infected plants (100 mg of tissue) was extracted using the NucleoSpin Kit (Macherey Nagel GmbH and Co., Duren, DE), according to the manufacturer's instructions, using the $\mathrm{C} 0$ buffer. DNA from $\approx 100 \mathrm{mg}$ of infected xylem vessels obtained from naturally infected plants was extracted using Kingfisher (Thermo, Waltham, MA) according to the manufacturer's protocols, followed by volume reduction to $20 \mu \mathrm{l}$, concentrating the solution with Concentrator 5301 (Eppendorf AG, Hamburg, DE). DNA concentrations were quantified on a spectrophotometer (Eppendorf AG) using ethidium bromide fluorescence analysis and were diluted according to experimental needs.

General description of the IR-SCAR technique. The strategy adopted to isolate DNA fragments flanking LTRs in $F$. oxysporum f. sp. lactucae by performing the IR-SCAR technique is outlined

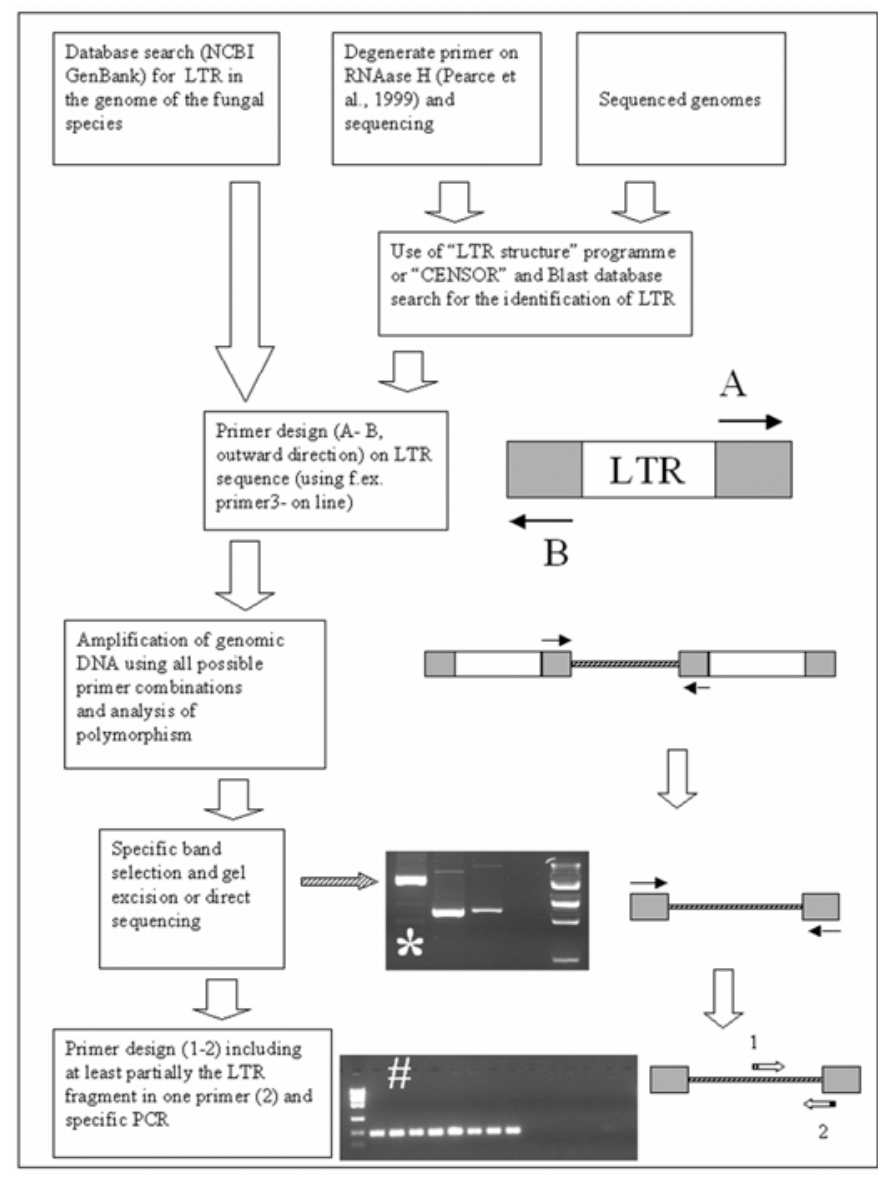

Fig. 1. Scheme describing a general procedure for the development of the inter-retrotransposon sequence-characterized amplified regions (IR-SCAR) technique, according to the different level of preexisting knowledge on the genome. Primers A and B are the inter-retrotransposon amplified polymorphism (IRAP) primers, and primers 1 and 2 are the SCAR primers. The first agarose gel (marked with *) shows the specific amplification fragment obtained in this work using the primer Hani on Fusarium oxysporum f. sp. lactucae race 1 isolates, product size 2,337 bp. From left to right: 4 (race 1); 9501 (race 2); MAFF744086 (race 3); water; and 1-kb plus marker. The second gel (marked with \#) represents the specific polymerase chain reaction (PCR) product obtained with primer Hani3' (primer 1 in figure)-Hanilatt3rev (primer 2 in figure), product size $187 \mathrm{bp}$. Lanes from left to right: 100-bp Invitrogen marker; the first eight isolates (13/04, 15/04, JCP 0024, ALFACE, Az-01, SB1-1, FOL11, and FOL18) belonging to f. sp. lactucae race 1; 9501, belonging to f. sp. lactucae race 2; MAFF744086, belonging to f. sp. lactucae race 3; Fol 40, belonging to type I isolate from Taiwan; ATCC16600, belonging to $\mathrm{f}$. sp. Conglutinans; 2bis (isolated from lettuce but non-pathogenic); and water. in Figure 1. If LTR retroelements are known in the genome, as in the case described here, it is possible to design primers directly from these sequences. In the case of a sequenced genome that is not completely annotated, it is possible to use bioinformatic programs such as LTR structure (41) or Censor (34) for the identification of putative LTRs. In the case of a completely unknown genome, retroelements can be identified using a degenerate primer approach as described by Pearce et al. (53), that proved to be a reliable method for other fungi (H. Komjati, personal communication). After primer design, the procedure is similar to the SCAR technique. All LTR primers were used in all possible combinations and polymorphism among isolates was evaluated. Putative specific bands were sequenced and primers were designed from the sequence. The specific primer design for the identification of subgroups of isolates should follow this rule: one primer should match the LTR junction (including a part of the LTR sequence and a part of the flanking region) and the other primer should completely match the sequence of the flanking region.

IRAP PCR. To map the distribution of LTRs in the genome, primers Gaga and Gagi were designed from the LTR sequence of Skippy, with GenBank accession number L34658; and Hana and Hani were designed from the Han solo-LTR sequence, with GenBank accession number AF076629. All primers used in this study (Table 2) were designed using the online version of Primer 3 (56). Melting temperature, dimer, and hairpin formation of primers were tested using Oligo 5.0 (Molecular Biology Insights, Inc., Cascade, CO).

To investigate the efficacy of IRAP PCR for mapping the distribution of LTR in the F. oxysporum genome, all possible combinations of primers were used with 54 isolates (Table 1, marked with \#) available at the beginning of this study: Hana, Hani, Gaga, Gagi, Hana-Hani, Hana-Gaga, Hana-Gagi, Hani-Gaga, HaniGagi, and Gaga-Gagi. IRAP-PCR was performed in a $25-\mu \mathrm{l}$ volume containing $200 \mu \mathrm{M}$ nucleotides, buffer, and Fast-start Taq DNA polymerase according to the manufacturer's instructions (Roche, Basel, Switzerland) and $100 \mathrm{ng}$ of genomic DNAs $(1 \mu \mathrm{l})$. Amplification reactions were conducted on a GeneAmp 9700 thermocycler (Applied Biosystems, Foster City, CA) programmed as follows: an initial step of $94^{\circ} \mathrm{C}$ for $5 \mathrm{~min}$; followed by $30 \mathrm{cy}-$ cles of $94^{\circ} \mathrm{C}$ for $10 \mathrm{~s}, 60^{\circ} \mathrm{C}$ for $50 \mathrm{~s}$, and $72^{\circ} \mathrm{C}$ for $2 \mathrm{~min} 30 \mathrm{~s}$; and a final elongation step of $72^{\circ} \mathrm{C}$ for $7 \mathrm{~min}$. Each IRAP-PCR reaction was repeated at least twice. Reproducibility of the assay was tested using two different DNA extractions from two single colonies obtained from a subset of 15 isolates (Table 1, marked with *). Each DNA preparation was tested twice for PCR reactions with a subsample of four randomly chosen primers combinations (Gaga, Hani, Gaga-Hani, and Hana-Gagi).

IRAP analysis. All the fragments generated by IRAP reactions were scored as 0 (absent) to 1 (present) following a visual examination of the gel profile. Bands with the same size were considered to be identical. Bands obtained with a single primer (Hani or Hana or Gaga or Gagi) were not scored if they were also present in the amplification products obtained with primer combinations in order to avoid double scoring of identical bands. Distance among isolates was calculated using Nei and Li's (46)

TABLE 2. Name and $5^{\prime}-3^{\prime}$ sequence of primers used in this study

\begin{tabular}{ll}
\hline Primer name & \multicolumn{1}{c}{ Sequence } \\
\hline Gaga & 5'-GGGAACCAACCGTCACA-3' \\
Gagi & 5'-TAACCGCTAGGGTCGTAACA-3' \\
Hana & 5'-CACGATTCACCTTAATATCTGACA-3' \\
Hani & 5'-GAACCCTCCAACATTCAACA-3' \\
Hani3' & 5'-CCCTCCAACATTCAACAACTG-3' \\
Hanilatt3rev & 5'-ATTCACTGTACACCAACCTTTT-3' \\
FLA0101F & 5'-CTTATACCCCTGCTAGTTCC-3' \\
FLA0101R & 5'-ATCGAGAACCAATCCAGCTG-3' \\
\hline
\end{tabular}

a Primers from Shimazu et al. (58). 
coefficient, producing a matrix that was clustered using the unweighted pairgroup method with arithmetic means (UPGMA) method (61) with 2,000 bootstrap replicates. All analyses and the graphics were carried out using Treecon 1.3 (68).

Cloning and sequencing. In order to generate a specific marker for race 1 isolates, the unique sequence obtained from PCR amplification using the Hani primer was gel purified using the Quicksorb Kit (Genomed, Reseach Triangle Park, NC) and was cloned into the Invitrogen TOPO 4.1 vector, following the manufacturer's protocol. The colonies were screened by PCR using the $M 13 F$ and $M 13 R$ primers and were sequenced in both directions using an ABI 3100 at BMR-Genomics (Padova, Italy).

Lasergene 6.0 software package (DNAstar, Madison, WI) and BLAST (1) were used for sequence analysis and database search in GenBank, respectively.

Specific PCR. From the specific sequence obtained by using the Hani primer alone on isolate 4, two IR-SCAR primers, specific to race 1 of $\mathrm{f}$. sp. lactucae, were developed: Hani3' and Hanilatt3rev (Table 2). Following the scheme for the IR-SCAR technique (Fig. 1), the first primer was designed to include in its sequence the sequence of the $3^{\prime}$ Han solo-LTR, whereas the second primer was designed from the $3^{\prime}$ flanking region of the Han solo-LTR. The PCR reactions with race-1-specific primers were carried out using 20- $\mu$ l reaction volumes containing $100 \mathrm{ng}$ of genomic DNA, $2 \mu \mathrm{l}$ of PCR buffer (Invitrogen, Carlsbad, CA),
$0.2 \mu$ of Platinum Taq polymerase (Invitrogen), $0.75 \mathrm{mM} \mathrm{MgCl}_{2}$, $200 \mathrm{mM}$ each nucleotide (Roche), and $0.5 \mathrm{mM}$ each primer Hani3' and Hanilatt3rev. Final PCR conditions, after the optimization in a Biometra $\mathrm{T}$ gradient thermal cycler (Goettingen, DE), were $94^{\circ} \mathrm{C}$ for $1 \mathrm{~min} ; 10$ touch-down cycles $\left(-0.5^{\circ} \mathrm{C}\right.$ each cycle), each consisting in a denaturation step at $94^{\circ} \mathrm{C}$ for $15 \mathrm{~s}$ and an annealing step at $66^{\circ} \mathrm{C}$ for $30 \mathrm{~s} ; 25$ cycles, each consisting of a denaturation step at $94^{\circ} \mathrm{C}$ for $15 \mathrm{~s}$ and an annealing step at $61^{\circ} \mathrm{C}$ for $30 \mathrm{~s}$; followed by a final extension cycle at $72^{\circ} \mathrm{C}$ for $2 \mathrm{~min}$. Ramping speed of the thermal cycler was set at $2^{\circ} \mathrm{C} / \mathrm{s}$. No extension time was included to increase specificity and speed of the reaction. To obtain better amplification from seed and plant tissues, the PCR was performed adding $0.2 \mu \mathrm{l}$ of bovine serum albumin (BSA) (Invitrogen) and $0.2 \mu \mathrm{l}$ of dimethyl sulfoxide (DMSO) (Fynzyme, Espoo, Finland) to each reaction. Then, $5 \mu \mathrm{l}$ of the amplification products was loaded in a $2.5 \%$ agarose (Eppendorf AG) gel and visualized using the Bio-Rad Geldoc analyzer (Hercules, CA). All PCR reactions were repeated at least two times. In planta and on seed detection was tested on two independent DNA extractions. DNA obtained from water-inoculated plants and pathogen-free seed were used as corresponding negative controls.

Comparison of specific PCR assays. In order to verify the efficacy on plant material of primers previously developed for race 1 identification by Shimazu et al. (58) in pure culture, a PCR

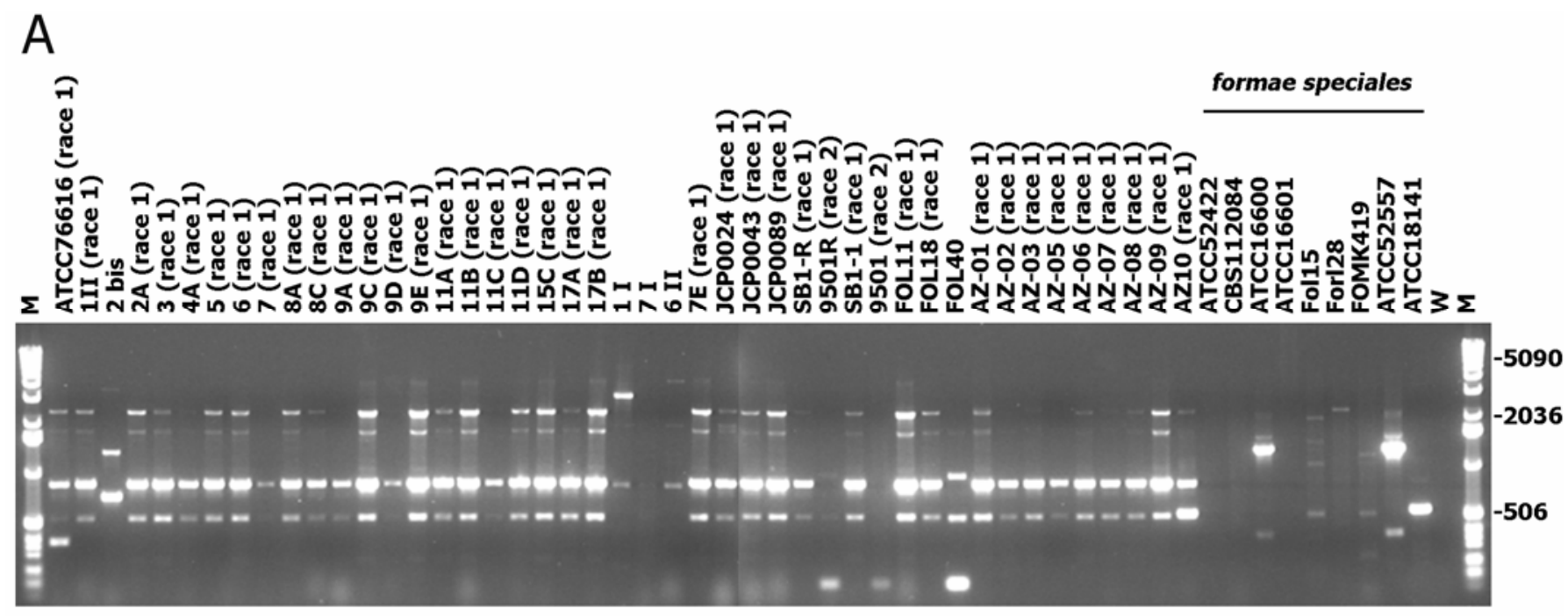

B

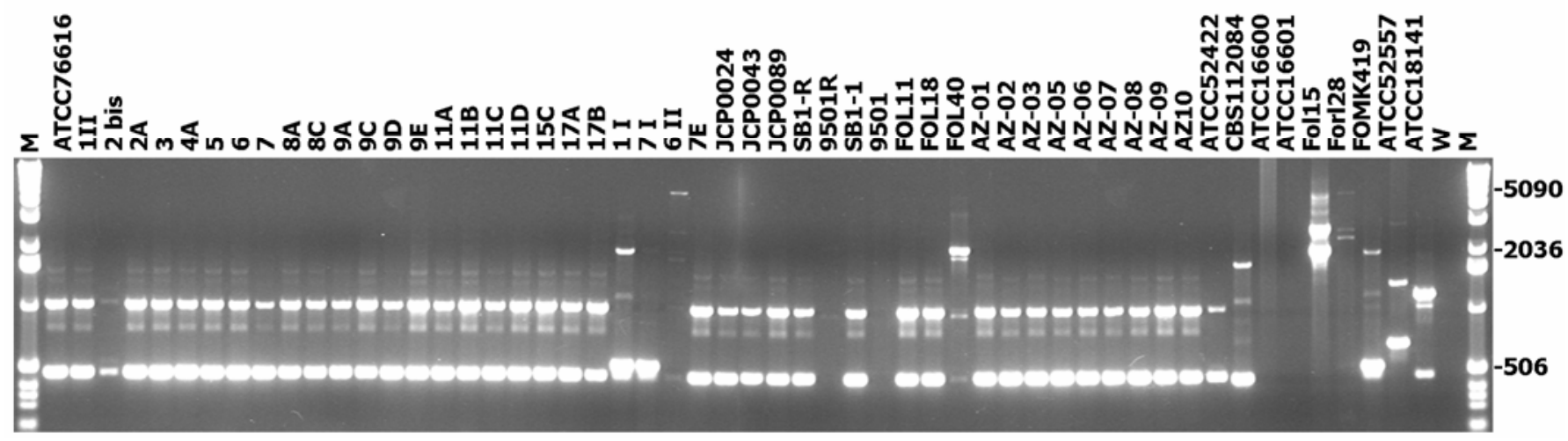

Fig. 2. A, Agarose gel electrophoresis of inter-retrotransposon amplified polymorphism (IRAP) polymerase chain reaction (PCR) products from genomic DNAs of Fusarium oxysporum by using the primer pair Hani-Gagi. B, Agarose gel electrophoresis of IRAP-PCR products from genomic DNAs of $F$. oxysporum by using the primer pair Hana-Hani. M = molecular size marker (1-kb DNAplus Ladder; Invitrogen, Carlsbad, CA). Molecular sizes are indicated on the right; W = negative control. 
was performed using primers FLA101F and FLA101R (Table 2). The assay was tested on DNA obtained from mycelial culture, from artificially infected seed (range dilution from 500 to $10 \mathrm{CFU}$ ), and from artificially infected plants (see above). The PCR was performed according to the protocol described previously (60). The only difference was that, in this study, the Platinum Taq polymerase (Invitrogen) and the Biometra thermal cycler were used. Moreover, because no amplification was obtained on vegetable material following the protocol described, in order to use identical optimized condition for plant amplification, $0.2 \mu \mathrm{l}$ of BSA (Invitrogen) and $0.2 \mu \mathrm{l}$ of DMSO (Fynzyme) were added to each reaction. Conditions were $3 \mathrm{~min}$ at $95^{\circ} \mathrm{C}$ followed by 25 cycles of $1 \mathrm{~min}$ at $95^{\circ} \mathrm{C}, 2 \mathrm{~min}$ at $60^{\circ} \mathrm{C}$, and $2 \mathrm{~min}$ at $72^{\circ} \mathrm{C}$; the final incubation was set at $72^{\circ} \mathrm{C}$ for $10 \mathrm{~min}$.

\section{RESULTS}

Pathogenicity assay. All isolates collected in 2003 to 2004 in Italy were pathogenic to lettuce. Isolates collected in 2002 were tested previously and shown to be pathogenic to lettuce (50). The previously untested isolate from Portugal was confirmed to be pathogenic to lettuce (Table 1). At 30 days after inoculation, plants infected with race 1 isolates all showed a rating of 5 .

IRAP-PCR. The reproducibility of the IRAP PCR was confirmed by confronting the bands from two different single colonies' DNA extracts. All the fragments amplified were identical in size among the different PCR reactions (data not shown).

IRAP PCR on the 54 isolates produced a large set of bands ranging from 150 to $7,000 \mathrm{bp}$. All the isolates, known to belong to race 1 VCG 0300 , had a very similar profile using the 10 possible primer combinations. In particular, IRAP profiles for European, American, Taiwanese type 2 isolates, and Japanese isolate SB1-1 were very similar. The race 2 Japanese isolate F9501 and the Taiwan isolate type1 (Fol 40) shared few bands, suggesting that the two groups have little similarity.

By comparing the IRAP profile of various formae speciales isolates and, in particular, f. sp. lactucae, it was possible to identify bands that were exclusively amplified from genomic DNA of VCG0300 (race 1) isolates but not from VCG 0301 and race 2 (Fig. 2A and B). Single specific bands also were obtained for some of the other formae speciales used in this study. In total, 129 polymorphic bands were scored. Similarity analysis revealed consistent grouping of VCGs. All isolates belonging to VCG 0300 (from Taiwan, Italy, the United States, and Japan) were clustered in the same group, while the race 2 isolate from Japan and the type 1 isolates from Taiwan grouped together with other formae speciales (Fig. 3).

Cloning and sequencing. The band identified at 2,337 bp obtained by the IRAP-PCR with the Hani primer on isolate 4 (Fig. 1 , marked by $*$ ), was present only in $F$. oxysporum $\mathrm{f}$. sp. lactucae (race 1) isolates. The PCR fragment was sequenced (GenBank accession number DQ208164) and primers were designed based on it. BlastN comparison of the sequence to the National Center for Biotechnology Information database showed nucleotide sequence similarity at $75 \%$ for the first $5^{\prime} 1,300 \mathrm{bp}$, with a region on chromosome 3 of the Gibberella zeae genome. The translated query (BlastX) confirmed $72 \%$ identity of the first 1,300 bp with a putative protein from $G$. zeae that has similarity with transpos-

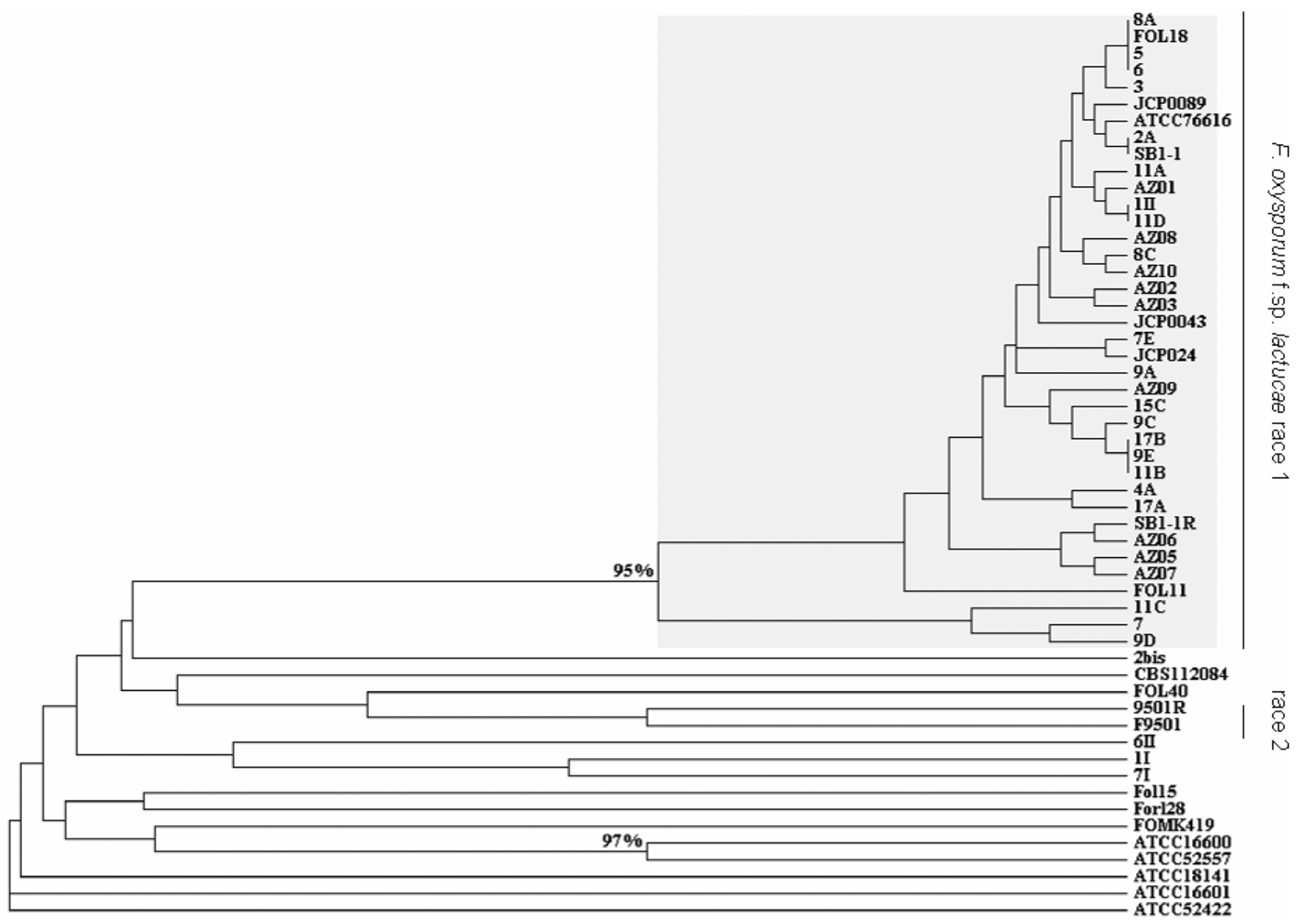

Fig. 3. Unweighted pairgroup method with arithmetic means representation of inter-retrotransposon amplified polymorphism (IRAP) results on subsamples of isolates from Table 1 . The gray rectangle shows Fusarium oxysporum f. sp. lactucae race 1 isolates on the tree branches. Bootstrap values (2,000 replicates) $>95 \%$ are provided. 
able elements in different species. In contrast, the last 1,000 bp showed no similarity with any known sequences.

Specific PCR. The primer pair hani3'-hanilatt3rev (product size $183 \mathrm{bp}$ ) was tested on all isolates belonging to different $F$. oxysporum formae speciales (Fig. 4) and on all other fungal species listed in Table 1. The PCR fragment was amplified exclusively for the 69 isolates of $F$. oxysporum f. sp. lactucae belonging to race 1 , as summarized in Table 1 . No amplicons were obtained for any other samples tested. The sensitivity of the assay, verified on a serial dilution of genomic DNA of the isolate SB1-1 and isolate 4, was estimated to range between 1 and $10 \mathrm{pg}$ (data not shown).

The specific PCR also was performed on DNA obtained from seed and plants artificially infected with isolate SB1-1 and 4. It was possible to detect the pathogen on plants artificially inoculated at a concentration of $10^{6}$ conidia/ml 15 days after inoculation and plants inoculated at a conidial concentration of $10^{4}$ conidia/ml 25 days after inoculation (Fig. 5A). Both groups of plants were symptomatic. The PCR performed on DNA obtained from 100 artificially infested seed at different CFU (ranging from
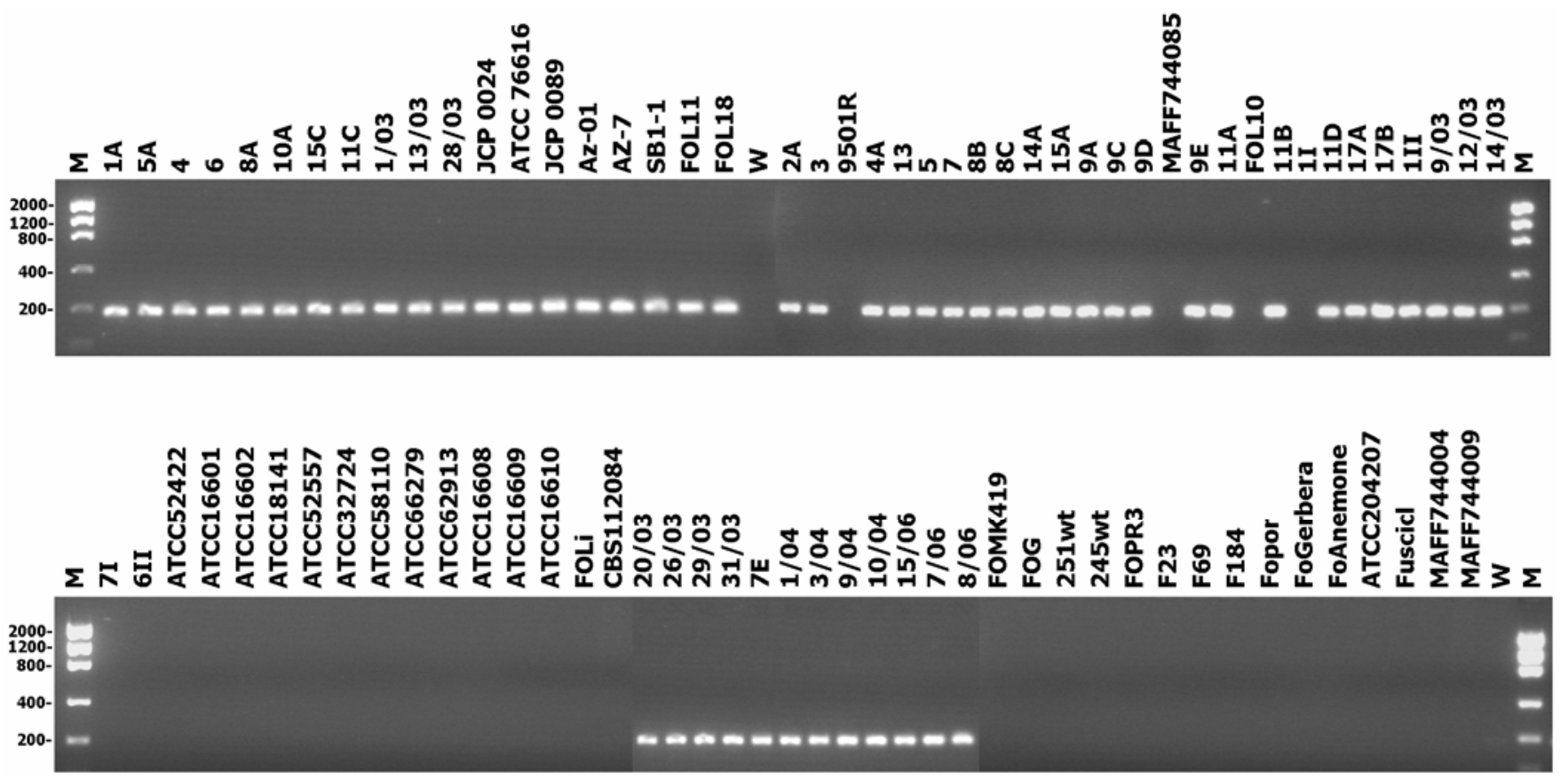

Fig. 4. Agarose gel electrophoresis of polymerase chain reaction (PCR) amplification using specific primers Hani3'-Hanilatt3rev on genomic DNAs of race 1, race 2, and race 3 of Fusarium oxysporum f. sp. lactucae and other $F$. oxysporum formae speciales. $\mathrm{M}=$ molecular size marker (Low DNA Mass Ladder; Invitrogen, Carlsbad, CA) and $\mathrm{W}=$ negative control. Molecular sizes are indicated on the left.
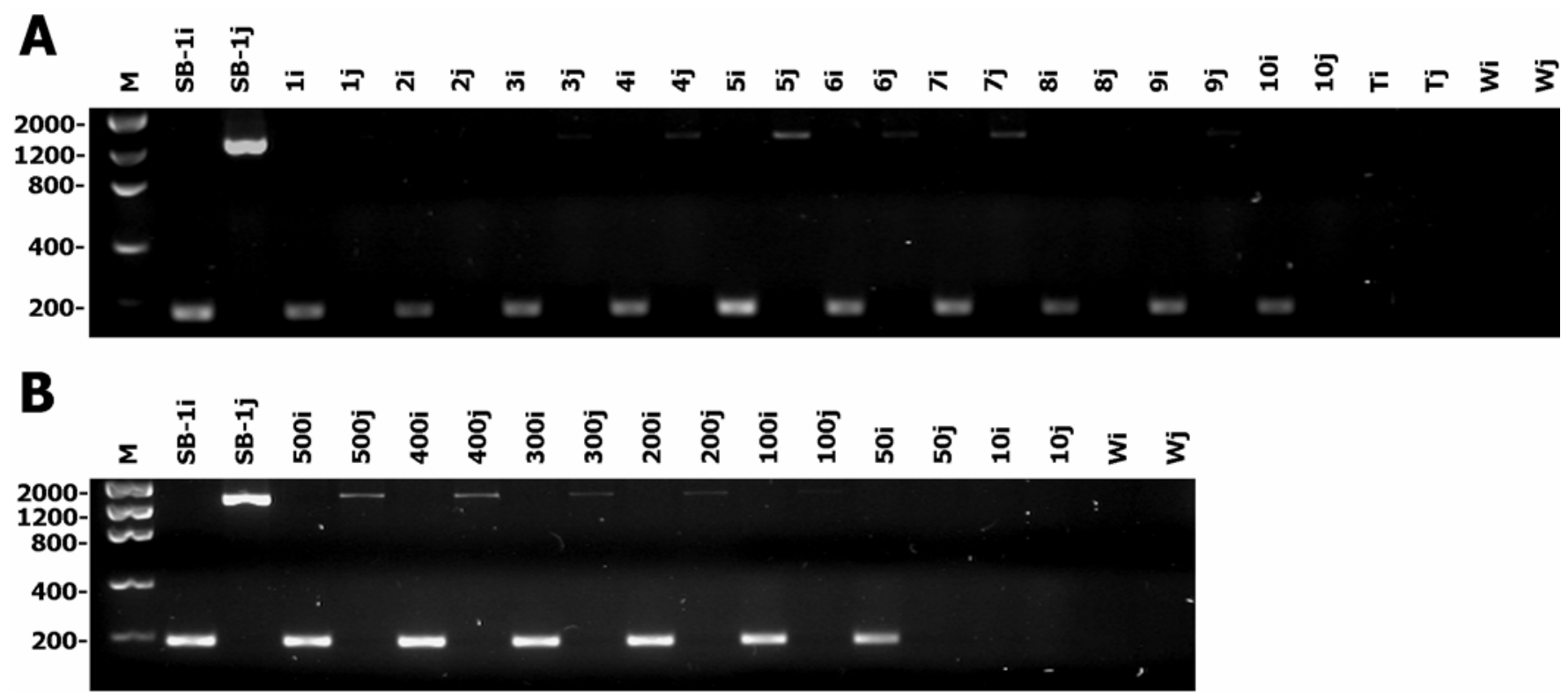

Fig. 5. Agarose gel electrophoresis of polymerase chain reaction (PCR) amplification using specific primers Hani3'-Hanilatt3rev (i) and primers FLA0101FFLA0101R (j) on DNA extracted from A, artificially infected plants; and B, seed at different colony forming unit (CFU) levels with isolate SB-1 of Fusarium oxysporum f. sp. lactucae. Numbers on top indicate the average number of CFU of the seed lot examined. SB-1 = genomic DNA used as positive control, $\mathrm{M}=$ molecular size marker (Low DNA Mass Ladder; Invitrogen, Carlsbad, CA), T = plant inoculated with water, and $\mathrm{W}=$ negative control. Molecular sizes are indicated on the left. 
500 to 10$)$ showed a sensitivity of the PCR assay of $50 \mathrm{CFU}( \pm 24$ standard deviation) per 100 seed (Fig. 5B). Finally, we tested the PCR on naturally infected plants from the field. The amplification from plants proved to be effective on symptomatic plants belonging to three different lettuce cultivars (Fig. 6).

Comparison of specific PCR assays. In order to verify the efficacy on plant material of the assay developed for the identification of race 1 from pure culture (58), the Japanese primers were tested on artificially infected plants. Only $60 \%$ of the plants (6 of 10) that were identified as infected by the IR-SCAR assay were positive using Japanese primers (Fig. 5A). The assay also was tested on artificially infected seed. Again, the IR-SCAR assay proved to be more sensitive than the test developed by Shimazu et al. (58). In fact, Japanese primers were able to identify the presence of the pathogen in seed up to $100 \mathrm{CFU}$ per 100 seed (Fig. 5B), compared with $50 \mathrm{CFU}$ per 100 seed for the newly developed assay.

\section{DISCUSSION}

In this article, a SCAR technique based on the analysis of distribution of retroelements was presented. A PCR assay for race 1 isolates of $F$. oxysporum f. sp. lactucae, the ubiquitous causal agent of Fusarium wilt on lettuce, was developed. The assay, based on the application of the IR-SCAR technique, was useful for the identification of the fungus on plant and seed. Reverse transcriptase sequences had been proposed for discriminating formae speciales of $F$. oxysporum (16). Here, it was confirmed that another approach can be followed for discriminating formae speciales or subpopulations, utilizing LTR distribution in the genome of $F$. oxysporum. The use of LTR insertion, known to be a stable marker in other organisms such as plants $(35,37)$, was proposed to differentiate isolates of $F$. oxysporum f. sp. lactucae and to investigate the level of polymorphisms among $F$. oxysporum isolates from lettuce. It was shown that it is possible to develop a specific PCR diagnostic method for the identification of the pathogen on lettuce seed and plants infected with race 1 (VCG0300) of F. oxysporum f. sp. lactucae from the analysis of IRAP amplification products.

The IRAP technique proved to be a reliable method for F. oxysporum identification, being both reproducible and able to generate polymorphisms among formae speciales. The technique clearly differentiated $F$. oxysporum isolates belonging to race 1 , VCG0300 from other isolates of $F$. oxysporum f. sp. lactucae and other formae speciales. The UPGMA tree (Fig. 3) suggests that the level of homogeneity of race 1 isolates is high and supports previous indications of a clonal origin of race 1 (50). In fact, there was no correlation between clustering in the UPGMA tree and geographic origin of race 1 isolates. This may be caused by the

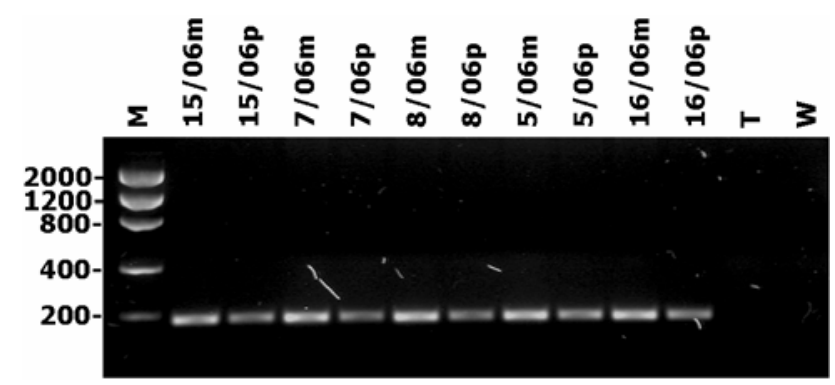

Fig. 6. Agarose gel electrophoresis of polymerase chain reaction (PCR) amplification using specific primers Hani3'-Hanilatt3rev on DNA extracted from $(\mathrm{m})$ mycelium and from $(\mathrm{p})$ naturally infected plants showing symptoms in the field. Isolates 15/06 and 8/06 are from the 'Foglia di quercia' cultivar; $7 / 06$ is from the 'multileaf' cultivar; and 5/06 and 16/06 are from the 'Batavia' cultivar. $\mathrm{M}=$ molecular size marker (Low DNA Mass Ladder; Invitrogen, Carlsbad, CA), $\mathrm{T}=$ healthy plant, and $\mathrm{W}=$ negative control for PCR. Molecular sizes are indicated on the left. high level of homogeneity of this race worldwide or by the inability to discriminate geographically structured populations within race 1 using the IRAP technique. Moreover, differential patterns for some representatives of other formae speciales used in this study were identified. Confirmation with a larger subset of samples is needed; however, these bands might be a source for genetic markers useful for the identification of formae speciales or subgroups.

The BLAST analysis of the inter-Hani LTR sequence of 2,337 bp showed similarities with a transposase protein of G. zeae and, to a lower extent, with one PEP protein of Nectria haematococca (63). Future studies might elucidate the role of the sequence in F. oxysporum f. sp. lactucae.

Comparing our previous experience with RAPD PCR (51) and LTR distribution analysis as source for specific sequences based on the IRAP technique, some advantages in using the latter technique were identified: the use of the IRAP-PCR for fingerprinting unknown species is faster than RAPD-PCR (45 min less for standard amplification protocols on GenAmp 9700, Applied Biosystem) and the use of specific primers reduces the potential risk for nonspecific products due to contamination that cannot be excluded by random priming approaches. Moreover, the analysis of retroelement movement and distribution may contribute to investigate the evolution of mobile elements (15). Because other sources of specific markers in F. oxysporum are class II transposable elements, it is worth exploring this type of transposable elements as a tool for genetic analysis. Class II transposons play an important role in the genome of fungal species $(14,59)$ and have been used for different research purposes $(12,29)$, including target mutagenesis, variability analysis, and gene identification. Because DNA transposons mobilize through complete excision (12), their use as genetic markers requires the verification of inactivity of the transposon in order to be used as reliable methods for primer development $(7,19)$. This is not required with LTR distribution, suggesting a constitutive advantage of the technique presented here over the use of class II transposons.

IRAP-PCR, using the primers developed here from known LTRs, is a valuable procedure for a first screening of unknown F. oxysporum samples and a potentially valuable source for developing SCAR primers. The major disadvantage of IRAP PCR is the need of previous knowledge of LTR sequences in the genome of study.

The other main objective of the work was to develop a fast PCR protocol for the identification of race 1 isolates on vegetable material. The primers developed with the IR-SCAR technique proved to be specific to the race 1 isolates obtained in different world regions, discriminating it from the new Japanese races 2 and 3, only present in Japan. The severity and worldwide spread of the pathogen require complex and integrated approaches. The use of valuable resistant cultivars $(23,42,65)$ and the adoption of helpful agronomic techniques (38) can be combined with effective chemical prevention methods such as the activation of acquired resistance through metabolic stimulation (67) or extensive seed screening and treatments for control of this disease (23-25). A complete prevention strategy requires an accurate, rapid, and efficient test for identification of the causal agent. The method described here improves upon the previously developed methodology for F. oxysporum f. sp. lactucae identification developed by a Japanese research group (58) by allowing identification of race 1, VCG 0300 isolates directly on seed or plants, without first subculturing the pathogen on a selective medium. Because Japanese primers were developed for identification of race 1 only in pure culture, we performed a comparative analysis with the primers developed in this study in vegetable material. Japanese primers showed a lower level of sensitivity while amplifying DNA from infected plants and seed. The comparison of the two assays, moreover, showed that the primers developed in this study allowed for a faster PCR procedure: in fact, the assay described here can be 
performed in $1 \mathrm{~h}$ whereas the Japanese assay requires $2 \mathrm{~h} 30 \mathrm{~min}$. This gain in time, coupled with the higher sensitivity, is valuable in terms of developing an efficient assay for screening vegetable material from the field. Given this aim of testing the efficacy of the newly developed primers under natural condition, a preliminary experiment was carried out with naturally infected plants from the field. Further studies will be needed in order to analyze the efficacy of the system with field isolates with various geographic origins; however, preliminary results showed that the type of lettuce is not influencing the efficacy of the assay. This PCR method represents a major step toward the development of a quick, standardized diagnostic tool for seed lot screening. Because a detection limit of $\approx 50$ CFU per 100 seed could not discriminate very low infection levels, our future studies on diagnostics of $F$. oxysporum $\mathrm{f}$. sp. lactucae will investigate more efficient and sensitive tools of seed detection such as specific probes used in real-time PCR assays (52).

\section{ACKNOWLEDGMENTS}

This work was financially supported by the EU Coordination Action (SSPE-CT-2004-006403) and by the Italian Ministry for the Environment Land and Sea (Accordo programmatico per la promozione dell'agricoltura sostenibile). We thank M. de Lurdes Marques Ramalhete for providing the Portuguese isolate, G. Gilardi for providing naturally infected plants, S. Gale and L. Gale for providing some DNA samples, C. Kistler for revising the manuscript, and anonymous reviewers for valuable suggestions.

\section{LITERATURE CITED}

1. Altschul, S. F., Gish, W., Miller, W., Myers, E. W., and Lipman, D. J. 1990. Basic local alignment search tool. J. Mol. Biol. 215:403-410.

2. Alves Santos, F. M., Ramos, B., Garcia Sanchez, M. A., Eslava, A. P., and Diaz Minguez, J. M. 2002. A DNA based procedure for in planta detection of Fusarium oxysporum f. sp. phaseoli. Phytopathology 92:237-244.

3. Anaya, N., and Roncero, M. I. G. 1995. Skippy, a retrotransposon from the fungal plant pathogen Fusarium oxysporum. Mol. Gen. Genet. 249:637-647.

4. Anaya, N., and Roncero, M. I. G. 1996. Stress-induced rearrangements of Fusarium retrotransposon sequences. Mol. Gen. Genet. 253:89-94.

5. Baayen, R. P., O’Donnell, K., Bonants, P. J. M., Cigelnik, E., Kroon, L. P. N. M., Roebrock, E. J. A., and Waalwijk, C. 2000. Gene genealogies and AFLP analyses in the Fusarium oxysporum complex identify monophyletic and nonmonophyletic formae speciales causing wilt and rot disease. Phytopathology 90:891-907.

6. Capy, P. 2005. Classification and nomenclature of retrotransposable elements. Cytogenet. Genome Res. 110:457-461.

7. Chiocchetti, A., Bernardo, I., Daboussi, M. J., Garibaldi, A., Gullino, M. L., Langin, T., and Migheli, Q. 1999. Detection of Fusarium oxysporum $\mathrm{f}$. sp. dianthi in carnation tissue by PCR amplification of transposon insertions. Phytopathology 89:1169-1175.

8. Chiocchetti, A., Ghignone, S, Minuto, A, Gullino, M. L., Garibaldi, A., and Migheli, Q. 1999. Identification of Fusarium oxysporum f. sp. basilici isolated from soil, basil seed, and plants by RAPD analysis. Plant Dis. 83:576-581

9. Chiocchetti, A., Sciaudone, L., Durando, F., Garibaldi, A., and Migheli, Q. 2001. PCR detection of Fusarium oxysporum f. sp. basilici on basil. Plant Dis. 85:607-611.

10. Causin, R., Scopel, C., Grendene, A., and Montecchio, L. 2005. An improved method for the detection of Phytophthora cactorum (L.C.) Schröeter in infected plant tissues using SCAR markers. J. Plant Pathol. 87:25-35

11. Daboussi, M. J. 1996. Fungal transposable elements: generators of diversity and genetic tools. J. Genet. 75:325-339.

12. Daboussi, M. J., and Capy, P. 2003. Transposable elements in filamentous fungi. Annu. Rev. Microbiol. 57:275-299.

13. Daboussi, M. J., and Langin, T. 1994. Transposable elements in the fungal plant pathogen Fusarium oxysporum. Genetica 93:49-59.

14. Davière, J. M., Langin, T., and Daboussi, M. J. 2001. Potential role of transposable elements in the rapid reorganization of the Fusarium oxysporum genome. Fungal Genet. Biol. 34:177-192.

15. Diez, J., Beguiristain, T., Le Tacon, F., Casacuberta, J. M., and Tagu, D. 2003. Identification of Ty1-copia retrotransposons in three ectomycorrhizal basidiomycetes: Evolutionary relationships and use as molecular markers. Curr. Genet. 43:34-44.
16. Di Pietro, A., Anaya, N., and Roncero, M. I. G. 1994. Occurrence of a retrotransposon-like sequence among different formae speciales and races of Fusarium oxysporum. Mycol. Res. 98:993-996.

17. Ellis, T. H. N., Poyser, S. J., Knox, M. R., Vershinin, A. V., and Ambrose, M. J. 1998. Polymorphism of insertion sites of Ty1-copia class retrotransposon and its use for linkage and diversity analysis in pea. Mol. Gen. Genet. 260:9-19.

18. Etebarian, H. R., Milani, M. J., and Alizadeh, A. 2001. Reaction of lettuce cultivars to Fusarium wilt (Fusarium oxysporum f. sp. lactucum). Seed Plant 17:275-285

19. Fernandez, D., Ouinten, M., Tantaoui, A., Geiger, J. P., and Langin, T. 1998. Fot1 insertions in the Fusarium oxysporum f. sp. albedinis genome provide diagnostic PCR target for detection of the date palm pathogen. Appl. Environ. Microbiol. 64:633-636.

20. Fujinaga, M., Ogiso, H. T. N., and Saito, H. 2001. Physiological specialization of Fusarium oxysporum f. sp. lactucae, a causal organism of Fusarium root rot of crisp head lettuce in Japan. J. Gen. Plant Pathol. 67:205-206.

21. Fujinaga, M., Ogiso, H., Tuchiya, N., Saito, H., Yamanaka, S., Nozue, M., and Kojima, M. 2003. Race 3, a new race of Fusarium oxysporum f. sp. lactucae determined by a differential system with commercial cultivars. J. Gen. Plant Pathol. 69:23-28.

22. Garibaldi, A., Gilardi, G., and Gullino, M. L. 2002. First report of Fusarium oxysporum on lettuce in Europe. Plant Dis. 86:1052.

23. Garibaldi, A., Gilardi, G., and Gullino, M. L. 2004. Varietal resistance of lettuce to Fusarium oxysporum f. sp. lactucae. Crop Prot. 23:845-851.

24. Garibaldi, A., Gilardi, G., and Gullino, M. L. 2004. Seed transmission of Fusarium oxysporum f. sp. lactucae. Phytoparasitica 32:61-65.

25. Gilardi, G., Tinivella, F., Gullino, M. L., and Garibaldi, A. 2005. Seed dressing to control Fusarium oxysporum f. sp. lactucae. J. Plant Dis. Prot. 112:240-246.

26. Giraud, T., Fortini, D., Levis, C., Leroux, P., and Brygoo, Y. 1997. RFLP markers show genetic recombination in Botryotinia fuckeliana (Botrytis cinerea) and transposable elements reveal two sympatric species. Mol. Biol. Evol. 14:1177-1185.

27. Goyon, C., Rossignol, J. L., and Faugeron, G. 1996. Native DNA repeats and methylation in Ascobolus. Nucleic Acids Res. 24:3348-3356.

28. Hua-Van, A., Davière, J. M., Kaper, F., Langin, T., and Daboussi, M. J. 2000. Genome organization in Fusarium oxysporum: Clusters of class II transposons. Curr. Genet. 37:339-347

29. Hua-Van, A., Pamphile, J., Langin, T., and Daboussi, M. J. 2001. Transposition in Fusarium oxysporum and a related species using autonomous and engineered impala transposons. Mol. Gen. Genet. 264:724-731.

30. Huang, J. H., and Lo, C. T. 1998. Wilt of lettuce caused by Fusarium oxysporum in Taiwan. Plant Pathol. Bull. 7:150-153.

31. Hubbard, J. C., and Gerik, J. C. 1993. A new wilt disease of lettuce incited by Fusarium oxysporum f. sp. lactucum forma specialis nov. Plant Dis. 77:750-754

32. Johnson, W. E., and Coffin, J. M. 1999. Constructing primate phylogenesis from ancient retrovirus sequences. Proc. Natl. Acad. Sci. USA 96:10254-10260.

33. Julien, J., Poirier-Hamon, S., and Brygoo, Y. 1992. Foret1, a reverse transcriptase-like sequence in the filamentous fungus Fusarium oxysporum. Nucleic Acids Res. 20:3933-3937.

34. Jurka, J., Kapitonov, V. V., Pavlicek, A., Klonowski, P., Kohany, O., and Walichiewicz, J. 2005. Repbase update, a database of eukaryotic repetitive elements. Cytogenet. Genome Res. 110:462-467.

35. Kalender, R. T. G., Regina, M., Suoniemi, A., and Schulman, A. 1999 IRAP and REMAP: two new retrotransposon-based DNA fingerprinting techniques. Theor. Appl. Genet. 98:704-711.

36. Lardner, R., Stummer, B. E., Sosnowski, M. R., and Scott, E. S. 2005. Molecular identification and detection of Eutypa lata in grapevine. Mycol. Res. 109:799-808.

37. Leigh, F., Kalendar, R., Lea, V., Lee, D., Donini, P., and Schulman, A. H. 2003 Comparison of the utility of barley retrotransposon families for genetic analysis by molecular marker techniques. Mol. Gen. Genomics 269:464-474.

38. Matheron, M. E. McCreight, J. D., Tickes, B. R., and Porchas, M. 2005. Effect of planting date, cultivar, and stage of plant development on incidence of Fusarium wilt of lettuce in desert production fields. Plant Dis. 89:565-570

39. Matheron, M. E., and Koike, S. T. 2003. First report of Fusarium wilt of lettuce caused by Fusarium oxysporum f. sp. lactucae in Arizona. Plant Dis. 87:1265.

40. Matuo, T., and Motohashi, S. 1967. On Fusarium oxysporum f. sp. lactucae n.f. causing root rot of lettuce. Trans. Mycol. Soc. Jpn. 8:13-15.

41. McCarthy, E. M., and McDonald, J. F. 2003. LTR_STRUC: A novel search and identification program for LTR retrotransposons. Bioinformatics 19:362-367. 
42. McCreight, J. D., Matheron, M. E., Tickes, B. R., and Platts, B. 2005. Fusarium wilt race 1 on lettuce. HortScience 40:529-531.

43. Mes, J. J., Haring, M. A., and Cornelissen, B. J. C. 2000. Foxy: An active family of short interspersed nuclear elements from Fusarium oxysporum. Mol. Gen. Genet. 263:271-280.

44. Mouyna, I., Renard, J. L., and Brygoo, Y. 1996. DNA polymorphism among Fusarium oxysporum f. sp. elaeidis populations from oil palm, using a repeated and dispersed sequence "Palm" Curr. Genet. 30:174-180.

45. Murata, H., Babasaki, K., and Yamada, A. 2005. Highly polymorphic DNA markers to specify strains of the ectomycorrhizal basidiomycete Tricholoma matsutake based on marY1, the long terminal repeat of gypsy-type retroelement marY1. Mycorrhiza 15:179-186.

46. Nei, M., and Li, W.-H. 1979. Mathematical model for studying genetic variation in terms of restriction endonucleases. Proc. Nat. Acad. Sci. USA 76:5269-5273.

47. Ogiso H., Fujinaga M., Saito H., Takehara T., and Yamanaka, S. 2002. Physiological races and vegetative compatibility groups of Fusarium oxysporum f. sp. lactucae isolated from crisphead lettuce in Japan. J. Gen. Plant. Pathol. 68:292-299.

48. Pasquali, M., Acquadro, A., Balmas, V., Migheli, Q., Garibaldi, A., and Gullino, M. L. 2003. RAPD characterization of Fusarium oxysporum isolates pathogenic on Argyranthemum frutescens L. J. Phytopathol. 151:30-35

49. Pasquali, M., Acquadro, A., Balmas, V., Migheli, Q., Garibaldi, A., and Gullino, M. L. 2004. Development of PCR primers for a new Fusarium oxysporum pathogenic on Paris daisy. Eur. J. Plant. Pathol. 110:7-11.

50. Pasquali, M., Gilardi, G., Gullino, M. L., and Garibaldi, A. 2003. Fusarium oxysporum f. sp. lactucae on lettuce: Vegetative compatibility and RAPD analysis. Inf. Fitopatol. 53:73-75. (In Italian)

51. Pasquali, M., Marena, L., Fiora, E., Piatti, P., Gullino, M. L., and Garibaldi, A. 2004. Real time PCR for the identification of a highly pathogenic group of Fusarium oxysporum f. sp. chrysanthemi on Argyranthemum frutescens L. J. Plant Pathol. 86:51-57.

52. Pasquali, M., Dematheis, F., Gilardi, G., Garibaldi, A., and Gullino, M. L. 2005. Vegetative Compatibility Grouping of Fusarium oxysporum f. sp. lactucae from lettuce. Plant Dis. 89:237-240.

53. Pearce, S., Stuart-Rogers, C., Knox, M., Kumar, A., Ellis, T., and Flavell, A. 1999. Rapid isolation of plant Ty1-copia group retrotransposons LTR sequences for molecular marker studies. Plant J. 18:383-393.

54. Quirin, E. A., Ogundiwin, E. A., Prince, J. P., Mazourek, M., Briggs, M. O., Chlanda, T. S., Kim, K. T., Falise, M., Kang, B. C., and Jahn, M. M. 2005. Development of sequence characterized amplified region (SCAR) primers for the detection of Phyto.5.2, a major QTL for resistance to Phytophthora capsici Leon. in pepper. Theor. Appl. Genet. 110:605-612.

55. Roncero, M. I. G., Hera, C., Ruiz-Rubio, M., Maceira, G., Madrid, M. P., Caracuel, Z., Calero, F., Delgado-Jarana, J., n-Rodréýguez, R. R., Martéýnez-Rocha, A. L., Velasco, C., Roa, J., n-Urdiroz, M. M., Cordoba, D., and Di Pietro, A. 2002. Fusarium as a model for studying virulence in soilborne plant pathogens. Physiol. Mol. Plant Pathol. 62:87-98.

56. Rozen, S., and Skaletsky, H. J. 2000. Primer3 on the WWW for general users and for biologist programmers. Pages 365-386 in: Bioinformatics
Methods and Protocols: Methods in Molecular Biology. S. Krawetz and S. Misener, eds. Humana Press, Totowa, NJ.

57. Shepherd, N. S., Schwarz-Sommer, Z., Blumberg vel Spalve, J., Gupta, M., Wienand, U., and Saedler, H. 1984. Similarity of the Cin1 repetitive family of Zea mays to eukaryotic transposable elements. Nature 307:185187.

58. Shimazu, J., Yamauchi, N., Hibi, T., Satou, M., Horiuchi, S., and Shirakawa, T. 2005. Development of sequence tagged site markers to identify races of Fusarium oxysporum f. sp. lactucae. J. Gen. Plant Pathol. 71:183-189.

59. Shnyreva, A. V. 2003. Transposable elements are the factors involved in various rearrangements and modifications of the fungal genomes. Russ. J. Genet. 39:505-518.

60. Skovgaard, K., Bødker, L., and Rosendahl, S. 2002. Population structure and pathogenicity of Fusarium oxysporum isolated from soil and root necrosis of pea (Pisum sativum L.) FEMS Microbiol. Ecol. 42:367-374.

61. Sneath, P. H. A., and Sokal, R. R. 1973. Pages 230-234 in: Numerical Taxonomy. W. H. Freeman and Company, San Francisco.

62. Taylor, E. J. A., Konstantinova, P., Leigh, F., Bates, J. A., and Lee, D. 2004. Gypsy-like retrotransposons in Pyrenophora: an abundant and informative class of molecular markers Genome 47:519-525.

63. Teunissen, H. A. S., Rep, M., Houterman, P. M., Cornelissen, B. J. C., and Haring, M. A. 2003. Construction of a mitotic linkage map of Fusarium oxysporum based on Foxy-AFLPs. Mol. Gen. Genomics 269:215-226.

64. Temporini, E. D., and Van Etten, H. D. 2002. Distribution of the pea pathogenicity (PEP) genes in the fungus Nectria haematococca mating population VI. Curr. Genet. 41:107-114.

65. Tsuchiya, N., Fujinaga, M., Ogiso, H., Usui, T., and Tsukada, M. 2004. Resistance tests and genetic resources for breeding Fusarium root rot resistant lettuce. J. Jpn. Soc. Hortic. Sci. 73:105-113.

66. Tsygankova, S. V., Ignatov, A. N., Boulygina, E. S., and Kuznetsov, B. B. 2004. Genetic relationships among strains of Xanthomonas campestris pv. campestris revealed by novel rep-PCR primers. Eur. J. Plant. Pathol. 110:845-853.

67. Umemura, K., Tanino, S., Nagatsuka, T., Koga, J., Iwata, M., Nagashima, K., and Amemiya, Y. 2004. Cerebroside elicitor confers resistance to Fusarium disease in various plant Species. Phytopathology 94:813-818.

68. Van de Peer, Y., and De Wachter, R. 1994. TREECON for Windows: A software package for the construction and drawing of evolutionary trees for the Microsoft Windows environment. Comput. Appl. Biosci. 10:569570.

69. Woo, S. L., Noviello, C., and Lorito, M. 1998. Source of molecular variability and applications in characterization of the plant pathogen Fusarium oxysporum. In: Molecular Variability of Fungal Pathogen. CAB International, Wallingford, UK.

70. Yamauchi, N., Horiuchi, S., and Satou, M. 2001. Pathogenicity Groups in Fusarium oxysporum f. sp. lactucae on horticultural types of lettuce cultivars. J. Gen. Plant Pathol. 67:288-290.

71. Yamauchi, N., Shimazu, J., Horiuchi, S., Satou, M., Horiuchi, S., and Shirakawa, T. 2004. Physiological races and vegetative compatibility groups of butterhead lettuce isolates of Fusarium oxysporum f. sp. lactucae in Japan. J. Gen. Plant Pathol. 70:308-313 